\title{
Study on hematological and serum biochemical parameters of Pulikulam cattle in a nucleus herd
}

\author{
G. Srinivasan ${ }^{1 *}$ and T. Sathiamoorthy ${ }^{1}$ \\ ${ }^{1}$ Pulikulam Cattle Research Station, Tamil Nadu Veterinary and Animal Sciences University, \\ Manamadurai - 630 606, Tamil Nadu, India
}

\begin{abstract}
The Pulikulam cattle breed is a native breed of Tamil Nadu mostly reared in southern districts. In this study normal reference values of hematological and serum biochemical values were determined in Pulikulam cattle reared in Pulikulam Cattle Research Station. The animals were randomly selected and divided into different groups based on their age and physiological status viz., calves, heifers, early lactation, mid lactation, late lactation and bulls. Each group consists of six animals. The hematological parameters and serum biochemical parameters were estimated with the help of the auto analyzer. The values for different parameters during different physiological stages were analyzed. It is concluded that the hematological value of Pulikulam cattle are within the normal referral value of bovine species and in serum biochemical values some parameters are varied. The hematological and serum biochemical values of Pulikulam cattle breed will be useful for academic purpose and helpful to identify the health and nutritional status of Pulikulam cattle breed.
\end{abstract}

Key words: Hemato-biochemical reference value, Indigenous cattle breed, Native cattle, Pulikulam cattle, Tamil Nadu

\section{INTRODUCTION}

The health status of the cow can be evaluated based on the hematological and serum biochemical parameters. In combination with clinical examination, hematological and serum biochemical analysis is used as a diagnostic tool in bovine medicine (Roland et al., 2014). The hematological and serum biochemical values provide baseline information of nutritional, physiological and health status of the animal (Osman and Al- Busadah, 2003). Hematological and serum biochemical parameters of cow were analyzed by many authors at various physiological conditions. Biochemical profile of healthy cows and reproductive disorder were studied by Ruginosu et al. (2011). Influence of lactation on biochemical profile of cows was studied by Filipejová, and Kováèik (2009). Changes in the hematological parameters due to environmental effect were studied by Mazzullo et al. (2014). Seifi et al. (2007) studied the variation in the biochemical profile of cows during transition period. Cozzi et al. (2011) had estimated the references values for blood parameters in Holstein cows. Influence of age on hematology and serum biochemical reference value for female Holstein cattle were studied by Lumsden et al. (1980). Sabasthin et al. (2012) studied the hematological and serum biochemical parameters in normal cyclic, pregnant and repeat breeding buffalos (Bubalus bubalis). Hematological profile of Indian native breed Hallikar cattle at its native tract was studied by Lankesh et al. (2015). In general, metabolic profile test will give health status of the cow in herd basis. Nutrition plays a major role in changing the metabolic profile of the animal (Dhiman et al., 1991; Khaled et al., 1999; Ingvartsen, 2006). National Bureau of Animal Genetic Resources (NBAGR), registered 50 Indigenous cattle breeds (NBAGR website, 2021). The accession number allotted by NBAGR for Pulikulam cattle is 
INDIA_CATTLE_1800_PULIKULAM_03035. Pulikulam cattle breed is primarily a draught breed, small in size and capable of endurance activities and is reared in the southern part of Tamil Nadu, India (Littlewood, 1936). This breed is locally popular for its vigour and can sustain even under feed and fodder scarcity (Srinivasan and Sathiamoorthy, 2020). The population of Pulikulam cattle was about 50,000 , of which 20,000 were breeding female (Singh et al., 2012). There is no data available on normal reference value of hematological and serum biochemical parameters of Pulikulam animals. Therefore the present study was designed to study the various hematological and serum biochemical parameters of Pulikulam cattle reared in nucleus herd.

\section{MATERIALS AND METHODS}

The blood samples were collected from the Pulikulam animals reared in Pulikulam Cattle Research Station, a constituent unit of Tamil Nadu Veterinary and Animal Sciences University. The study was conducted in the month of October, 2020. The animals were randomly selected and divided into different groups based on their age and physiological status viz calves, heifers, early lactation, mid lactation, late lactation and bulls. Each group consists of six animals. The animals were reared in intensive housing system. All the animals were in good health condition and fed with green fodder, dry fodder and concentrate feed based on the ICAR, 2013 requirement. Blood samples were collected as per the standard procedure during early morning before feeding. The ethylenediamine tetraacetic acid (EDTA) was used as anticoagulant for collection of whole blood $(2 \mathrm{~mL})$ and another blood sample was collected without anticoagulant $(8 \mathrm{~mL})$ for collection of serum. Serum was harvested after standing the blood for 30 minutes and then centrifuging it at $3000 \mathrm{rpm}$ for 20 minutes. The hematological parameters such as hemoglobin $(\mathrm{Hb})$, packed cell volume (PCV), red blood cell (RBC) count, white blood cell (WBC) count, platelet count, neutrophils count, lymphocyte count, monocytes count and eosinophils and serum biochemical parameters such as albumin, globulin, blood urea nitrogen, serum creatinine, alanine aminotransferase (ALT), aspartate aminotransferase (AST), alkaline phosphatase (ALP), total bilurubin (Tbill), direct bilurubin (Dbill), serum calcium, phosphorus, magnesium, sodium, potassium and choloride were estimated. The mean corpuscular value (MCV), mean corpuscular hemoglobin concentration (MCHC) and mean corpuscular hemoglobin $(\mathrm{MCH})$ values were calculated (William O Reece, 2004). Hematological parameters were analyzed by auto hematology model Cellenium 21 and Labmate model for serum biochemical parameters. Data were subjected to analysis of variance (ANOVA) and Tukeys test using IBM SPSS Version 20. The statement of significant was considered on a probability of $\mathrm{p}<0.05$.

\section{RESULTS}

\section{Hematological parameters}

The hematological value for different parameters in the Pulikulam cattle is presented in Table 1. Highest $\mathrm{Hb}$ level was noticed in heifers and lowest $\mathrm{Hb}$ level was noticed in calves. The mean $\mathrm{Hb}$ concentrations during early, mid and late stage of lactation were $13.93 \pm 1.08,14.45 \pm 1.10$ and $15.0 \pm 1.19 \mathrm{~g} / \mathrm{dL}$ respectively. The mean values of packed cell volume and RBC were within normal physiological range of bovine. Platelet count was within the normal physiological range but significant difference $(\mathrm{p}<0.05)$ was noticed between calves and other groups. The mean leucocytes value was within the normal physiological range of bovine and significant difference $(\mathrm{p}<0.05)$ was noticed between calves and heifers. The mean corpuscular value (MCV) was within the normal physiological values of bovine but significant difference $(\mathrm{p}<0.05)$ was noticed between calves and bulls. Mean corpuscular hemoglobin concentration (MCHC) values were within the normal range. 
Table 1. Mean (Mean \pm SE) hematological value in Pulikulam breed of cattle

\begin{tabular}{|c|c|c|c|c|c|c|}
\hline Parameters & Calf & Heifer & $\begin{array}{l}\text { Early } \\
\text { lactation }\end{array}$ & $\begin{array}{l}\text { Mid } \\
\text { lactation }\end{array}$ & $\begin{array}{l}\text { Late } \\
\text { lactation }\end{array}$ & Bull \\
\hline $\mathrm{Hb}(\mathrm{g} / \mathrm{dL})$ & $11.5 \pm 0.56$ & $15.06 \pm 1.36$ & $13.93 \pm 1.08$ & $14.45 \pm 1.10$ & $15.00 \pm 1.19$ & $13.6 \pm 0.55$ \\
\hline PCV $(\%)$ & $27.33 \pm 1.11$ & $37.40 \pm 3.13$ & $33.56 \pm 2.2$ & $37.25 \pm 2.49$ & $36.66 \pm 2.95$ & $34.76 \pm 0.76$ \\
\hline $\mathrm{RBC}\left(\mathrm{x} 10^{6} \mu \mathrm{L}\right)$ & $7.91 \pm 0.33$ & $8.93 \pm 0.79$ & $7.94 \pm 0.51$ & $7.75 \pm 0.08$ & $7.97 \pm 0.71$ & $7.04 \pm 0.45$ \\
\hline $\mathrm{WBC}\left(\mathrm{x} 10^{3} \mu \mathrm{L}\right)$ & $10.933^{b} \pm 0.27$ & $6.266^{\mathrm{a}} \pm 0.87$ & $9.933^{\mathrm{ab}} \pm 1.18$ & $7.800^{\mathrm{ab}} \pm 1.63$ & $7.300^{\mathrm{ab}} \pm 0.78$ & $7.700^{\mathrm{ab}} \pm 0.78$ \\
\hline $\operatorname{MCV}(f l)$ & $34.5^{\mathrm{a}} \pm 0.09$ & $41.9^{\mathrm{ab}} \pm 0.17$ & $42.7^{\mathrm{ab}} \pm 0.43$ & $47.9^{\mathrm{b}} \pm 0.32$ & $46.1^{\mathrm{ab}} \pm 0.15$ & $47.0^{\mathrm{b}} \pm 0.28$ \\
\hline $\mathrm{MCH}(\mathrm{pg})$ & $14.52^{\mathrm{a}} \pm 0.02$ & $16.88^{\mathrm{ab}} \pm 0.07$ & $17.51^{\mathrm{b}} \pm 0.03$ & $18.61^{\mathrm{b}} \pm 0.12$ & $18.86 \mathrm{~b} \pm 0.04$ & $19.38^{\mathrm{b}} \pm 0.05$ \\
\hline $\mathrm{MCHC}(\%)$ & $42.04 \pm 0.01$ & $40.23 \pm 0.01$ & $42.08 \pm 0.05$ & $38.75 \pm 0.01$ & $40.91 \pm 0.01$ & $39.10 \pm 0.01$ \\
\hline Platelets (lakhs) & $5.79^{\mathrm{a}} \pm 0.61$ & $3.54^{\mathrm{b}} \pm 0.78$ & $2.96^{\mathrm{b}} \pm 0.29$ & $3.07^{\mathrm{b}} \pm 0.35$ & $3.19^{\mathrm{b}} \pm 0.40$ & $2.86^{\mathrm{b}} \pm 0.10$ \\
\hline Neutrophils (\%) & $26.68 \pm 1.15$ & $28 \pm 1.45$ & $29.68 \pm 0.66$ & $29.34 \pm 1.63$ & $31.68 \pm 2.84$ & $28.34 \pm 2.33$ \\
\hline Lymphocytes(\%) & $67.66 \pm 0.33$ & $66.67 \pm 1.73$ & $65 \pm 0.5$ & $65.5 \pm 2.85$ & $62.66 \pm 2.72$ & $66.33 \pm 2.02$ \\
\hline Monocytes (\%) & $2.66 \pm 0.33$ & $1.33 \pm 0.33$ & $1.66 \pm 0.33$ & $1.66 \pm 0.81$ & $1.66 \pm 0.33$ & $2.0 \pm 0.57$ \\
\hline Eosinophils (\%) & $3.0^{\mathrm{ab}} \pm 0.57$ & $4.0^{\mathrm{b}} \pm 0.57$ & $3.66^{\mathrm{b}} \pm 0.33$ & $3.50^{\mathrm{a}} \pm 0.40$ & $4.0^{\mathrm{b}} \pm 0.57$ & $3.33^{\mathrm{ab}} \pm 0.33$ \\
\hline Basophils (\%) & 0 & 0 & 0 & 0 & 0 & 0 \\
\hline
\end{tabular}

(Values are mean of six replicates)

Mean with different superscript in a row differ significantly $(\mathrm{P}<0.05)$

Mean corpuscular hemoglobin $(\mathrm{MCH})$ values were within the normal physiological range of bovine but significant difference $(\mathrm{p}<0.05)$ was noticed in between calf and early, mid and late lactation groups. The mean value of neutrophils was higher in bulls $(28.34 \pm 2.33 \%)$ than calves $(26.68 \pm 1.15 \%)$, but highest value was noticed in late lactation group (31.68 $2.84 \%)$. However lymphocyte count was higher in calves $(67.66 \pm 0.33 \%)$ than bulls $(66.33 \pm 2.02 \%)$. The circulating eosinophils level was higher in late lactation group $(4.0 \pm 0.57 \%)$ and heifers $(4.0 \pm 0.57 \%)$ and lower in calves $(3.0 \pm 0.57 \%)$. A significant difference $(\mathrm{p}<0.05)$ was noticed between mid and late lactation group. The mean values of monocytes count were within normal physiological range of bovine, highest value were observed in calves $(2.66 \pm 0.33 \%)$. No basophil count was reported in this study in different age group of Pulikulam animals.

\section{Serum biochemical parameters}

The mean serum biochemical parameters values are given in Table 2. The serum glucose level of Pulikulam cattle ranged from 82 to $117.66 \mathrm{mg} / \mathrm{dL}$. Highest mean serum glucose level was noticed in calves $(117.66 \pm 8.68 \mathrm{mg} / \mathrm{dL})$ and lowest mean serum glucose level noticed in early lactation group $(82.0 \pm 7.02 \mathrm{mg} / \mathrm{dL})$. The mean total protein was highest $(6.43 \pm 0.23 \mathrm{~g} / \mathrm{dL})$ in late lactation, the values of early lactation $(6.2 \pm 0.3 \mathrm{~g} / \mathrm{dL})$ and mid lactation $(6.15 \pm 0.15 \mathrm{~g} / \mathrm{dL})$ group were almost at par. The serum albumin was higher in early lactation than mid and late lactation. The globulin level was higher in mid lactation $(2.75 \pm 0.28$ $\mathrm{g} / \mathrm{dL})$ and late lactation $(2.7 \pm 0.20 \mathrm{~g} / \mathrm{dL})$ than early lactation $(2.36 \pm 0.20)$. A significant difference $(\mathrm{p}<0.05)$ in globulin level was noticed between calves and mid lactation group. The mean BUN values in heifers, early, mid and late lactation stages were $73.1 \pm 4.13 \mathrm{mg} / \mathrm{dL}$, 
Blood parameters of Pulikulam animals

Table 2. Mean (Mean \pm SE) serum biochemical value in Pulikulam breed of cattle

\begin{tabular}{|c|c|c|c|c|c|c|}
\hline Parameters & Calf & Heifer & $\begin{array}{l}\text { Early } \\
\text { lactation }\end{array}$ & $\begin{array}{l}\text { Mid } \\
\text { lactation }\end{array}$ & $\begin{array}{l}\text { Late } \\
\text { lactation }\end{array}$ & Bull \\
\hline $\begin{array}{l}\text { Glucose } \\
(\mathrm{mg} / \mathrm{dL})\end{array}$ & $117.66 \pm 8.68$ & $97.0 \pm 6.65$ & $82.0 \pm 7.02$ & $93.5 \pm 26.53$ & $89.66 \pm 1.76$ & $106.0 \pm 1.0$ \\
\hline $\begin{array}{l}\text { Albumin } \\
(\mathrm{g} / \mathrm{dL})\end{array}$ & $3.63 \pm 0.12$ & $3.73 \pm 0.14$ & $3.83 \pm 0.18$ & $3.4 \pm 0.16$ & $3.73 \pm 0.08$ & $3.6 \pm 0.15$ \\
\hline $\begin{array}{l}\text { Globulin } \\
(\mathrm{g} / \mathrm{dL})\end{array}$ & $1.46^{\mathrm{a}} \pm 0.31$ & $2.46^{\mathrm{ab}} \pm 0.31$ & $2.36^{\mathrm{ab}} \pm 0.20$ & $2.75^{\mathrm{b}} \pm 0.28$ & $2.7^{\mathrm{ab}} \pm 0.20$ & $2.46^{\mathrm{ab}} \pm 0.35$ \\
\hline $\begin{array}{l}\text { Total Protein } \\
\text { (g/dL) }\end{array}$ & $5.1 \pm 0.37$ & $6.2 \pm 0.11$ & $6.2 \pm 0.30$ & $6.15 \pm 0.15$ & $6.43 \pm 0.23$ & $6.06 \pm 0.23$ \\
\hline $\begin{array}{l}\mathrm{BUN} \\
(\mathrm{mg} / \mathrm{dL})\end{array}$ & $68.8 \pm 6.55$ & $73.1 \pm 4.13$ & $66.7 \pm 4.25$ & $83.2 \pm 0.73$ & $68.73 \pm 4.71$ & $69.90 \pm 1.10$ \\
\hline $\begin{array}{l}\text { Creatinine } \\
(\mathrm{mg} / \mathrm{dL})\end{array}$ & $1.70^{\mathrm{a}} \pm 0.05$ & $2.1^{\mathrm{b}} \pm 0.05$ & $2.0^{\mathrm{ab}} 3 \pm 0.03$ & $2.0^{\mathrm{b}} \pm 0.16$ & $2.3^{\mathrm{b}} \pm 0.05$ & $2.03^{\mathrm{ab}} \pm 0.06$ \\
\hline $\begin{array}{l}\text { Cholestrol } \\
(\mathrm{mg} / \mathrm{dL})\end{array}$ & $178.66 \pm 26.19$ & $147.33 \pm 3.17$ & $147.33 \pm 6.74$ & $169.0 \pm 15.51$ & $147.66 \pm 2.60$ & $139.0 \pm 9.29$ \\
\hline $\begin{array}{l}\text { Triglycerides } \\
(\mathrm{mg} / \mathrm{dL})\end{array}$ & $55.7 \pm 3.30$ & $52.53 \pm 2.40$ & $63.23 \pm 8.87$ & $62.25 \pm 3.22$ & $63.56 \pm 4.40$ & $36.56 \pm 5.26$ \\
\hline ALT (U/L) & $26.66^{\mathrm{ab}} \pm 2.96$ & $29.0^{\mathrm{ab}} \pm 2.0$ & $23.33^{\mathrm{b}} \pm 1.76$ & $26.5^{\mathrm{ab}} \pm 0.40$ & $21.66^{\mathrm{b}} \pm 1.20$ & $23.33^{\mathrm{a}} \pm 1.66$ \\
\hline AST (IU/dL) & $66.0 \pm 4.50$ & $66.0 \pm 2.08$ & $63.33 \pm 1.85$ & $69.5 \pm 2.04$ & $65.66 \pm 1.66$ & $69.66 \pm 4.97$ \\
\hline ALP (U/L) & $223.66 \pm 49.41$ & $140.0 \pm 7.09$ & $189.33 \pm 18.70$ & $124.50 \pm 1.22$ & $90.66 \pm 17.33$ & $210.33 \pm 56.0$ \\
\hline Dbill (mg/dL) & $0.05 \pm 0.01$ & $0.04 \pm 0.01$ & $0.02 \pm 0.01$ & $0.05 \pm 0.00$ & $0.05 \pm 0.01$ & $0.05 \pm 0.01$ \\
\hline Tbill (mg/dL) & $0.26^{\mathrm{a}} \pm 0.12$ & $0.41^{\mathrm{ab}} \pm 0.05$ & $0.35^{\mathrm{ab}} \pm 0.10$ & $0.43^{b} \pm 0.11$ & $0.37^{\mathrm{ab}} \pm 0.05$ & $0.44^{\mathrm{ab}} \pm 0.05$ \\
\hline
\end{tabular}

(Values are mean of six replicates)

Mean with different superscript in a row differ significantly $(\mathrm{P}<0.05)$

$66.7 \pm 4.25 \mathrm{mg} / \mathrm{dL}, 83.2 \pm 0.73 \mathrm{mg} / \mathrm{dL}$ and $68.73 \pm 4.71 \mathrm{mg} / \mathrm{dL}$ respectively. The mean serum creatinine values of Pulikulam cattle during early, mid and late lactation were $2.03 \pm 0.03$ $\mathrm{mg} / \mathrm{dL}, 2.0 \pm 0.16 \mathrm{mg} / \mathrm{dL}$ and $2.3 \pm 0.05 \mathrm{mg} / \mathrm{dL}$ respectively. But significant difference $(\mathrm{p}<0.05)$ was noticed between calves and mid, late lactation groups. The highest serum cholesterol level was noticed during mid lactation $(169.0 \pm 15.5 \mathrm{mg} / \mathrm{dL})$ followed by late lactation group early lactation group, and heifers viz $147.66 \pm 2.60 \mathrm{mg} / \mathrm{dL}, 147.33 \pm 6.74 \mathrm{mg} / \mathrm{dL}$ and $147.33 \pm 3.17 \mathrm{mg} / \mathrm{dL}$ respectively. The significant difference $(p<0.05)$ in triglyceride value was noticed between bulls and early lactation group. The ALT value reported in this study was within the normal physiological range of cattle. Highest value was observed in heifers $(29.0 \pm 2.0 \mathrm{U} / \mathrm{L})$ followed by calves $(26.66 \pm 2.96 \mathrm{U} / \mathrm{L})$. The lowest value was noticed in late lactation group $(21.66 \pm 1.2 \mathrm{U} / \mathrm{L})$.

The mean AST values noticed in this study was within the normal physiological range of bovine in all stage of lactation. The mean ALP value of Pulikulam cattle in the present study was within the normal physiological range. Highest ALP values noticed in calves $(223.66 \pm 49.41 \mathrm{U} / \mathrm{L})$ followed by bulls $(210.33 \pm 56.0 \mathrm{U} / \mathrm{L})$ and early lactation (189.33 $\pm 18.70 \mathrm{U} / \mathrm{L})$. Both mean total billurubin and direct billurubin values were within the normal physiological range of cattle (Kahn, $2010)$ but significant difference $(\mathrm{p}<0.05)$ in total billurubin level was noticed between calves and mid lactation group.

The mean serum calcium values of 
Table 3. Mean (Mean \pm SE) serum minerals level in Pulikulam cattle breed

\begin{tabular}{lllllll}
\hline Parameters & Calf & Heifer & $\begin{array}{l}\text { Early } \\
\text { lactation }\end{array}$ & $\begin{array}{l}\text { Mid } \\
\text { lactation }\end{array}$ & $\begin{array}{l}\text { Late } \\
\text { lactation }\end{array}$ & Bull \\
\hline $\begin{array}{l}\text { Calcium } \\
(\mathrm{mg} / \mathrm{dL})\end{array}$ & $7.8 \pm 0.20$ & $7.36 \pm 0.17$ & $7.63 \pm 0.26$ & $7.6 \pm 0.40$ & $7.73 \pm 0.12$ & $7.06 \pm 0.12$ \\
$\begin{array}{l}\text { Phosphorus } \\
(\mathrm{mg} / \mathrm{dL})\end{array}$ & $8.23 \pm 0.78$ & $6.86 \pm 0.41$ & $5.56 \pm 1.39$ & $7.7 \pm 0.32$ & $5.9 \pm 0.20$ & $5.66 \pm 0.44$ \\
$\begin{array}{l}\text { Magnesium } \\
(\mathrm{mg} / \mathrm{dL})\end{array}$ & $3.93 \pm 0.03$ & $3.96 \pm 0.06$ & $3.93 \pm 0.06$ & $3.95 \pm 0.12$ & $4.0 \pm 0.05$ & $3.86 \pm 0.03$ \\
$\begin{array}{l}\text { Sodium } \\
(\mathrm{mmol} / \mathrm{L})\end{array}$ & $162.49 \pm 2.93$ & $170.01 \pm 2.24$ & $162.49 \pm 6.12$ & $159.89 \pm 0.57$ & $164.56 \pm 0.87$ & $161.52 \pm 2.31$ \\
$\begin{array}{l}\text { Potassium } \\
(\mathrm{mmol} / \mathrm{L})\end{array}$ & $5.09 \pm 0.08$ & $4.39 \pm 0.23$ & $4.65 \pm 0.13$ & $4.87 \pm 0.89$ & $5.06 \pm 0.52$ & $4.02 \pm 0.20$ \\
$\begin{array}{l}\text { Chloride } \\
\text { (mmol/L) }\end{array}$ & $115.71 \pm 0.89$ & $114.09 \pm 3.0$ & $107.62 \pm 1.37$ & $111.11 \pm 3.15$ & $113.12 \pm 2.70$ & $111.43 \pm 1.10$ \\
\hline
\end{tabular}

(Values are mean of six replicates)

Pulikulam cattle are given in Table 3 . The serum calcium level was similar in all stages of lactation. The highest serum calcium level was notice during late lactation stage $(7.73 \pm 0.12$ $\mathrm{mg} / \mathrm{dL}$ ) followed by early and mid lactation cows. The serum phosphorus level was lower during early lactation $(5.56 \pm 1.3 \mathrm{mg} / \mathrm{dL})$ as compared to mid $(7.7 \pm 0.32 \mathrm{mg} / \mathrm{dL})$ and late lactation $(5.9 \pm 0.20 \mathrm{mg} / \mathrm{dL})$. The mean serum magnesium level was almost similar in all stages of lactation. The mean serum sodium, serum potassium and serum chloride levels were higher in late lactation group as $164.56 \pm 0.87$, $5.06 \pm 0.52$ and $113.12 \pm 2.70 \mathrm{mmol} / \mathrm{dL}$, respectively.

\section{DISCUSSION}

\section{Hematological parameters}

The mean $\mathrm{Hb}$ concentration was within the normal physiological range of cattle as reported by Jain (1986) ranged from $11.5 \pm 0.56$ to $15.06 \pm 1.36 \mathrm{~g} / \mathrm{dL}$. The mean haemoglobin level was in agreement with the values reported by Raghunandanan et al. (1977) and Mahima et al. (2013) in Hariana Cattle, Pyne and Maitra (1981) in Sahiwal cattle and Deshpande et al. (1986) in Red Kandhari cattle. The findings of packed cell volume, $\mathrm{MCV}, \mathrm{MCH}$ and $\mathrm{MCHC}$ values were within the normal physiological range of cattle as reported by Jain (1986). Jacob et al. (2019) reported that there was no significant difference in PCV value between lactating Gir cattle. The observation was in agreement with the findings of various workers in different indigenous breeds such as Raghunandanan et al. (1977) and Mahima et al. (2013) in Hariana Cattle, Pyne and Maitra (1981) in Sahiwal cattle, Deshpande et al. (1986) in Red Kandhari cattle. The mean value of TEC was within the normal range of cattle as reported by Jain (1986). Mahima et al. (2013) reported that RBC and TLC of Hariana cattle were within the normal physiological range. Variation in the reference values of TLC was reported by various authors due to difference in age, breed, environmental temperature, physiological status, stress prior to handling and parasitic infection (Kapale et al., 2008; Farooq et al., 2011). The circulating TLC generally represents the dynamic production by bone marrow, the release of the cells to the peripheral circulation and their storage in different organs or pools. Jacob (2012) reported that Gir bulls were found to have higher TLC than male calves with different age. Shil et al. (2012) found that 
lymphocyte count was higher in calves than bulls which were similar to the findings of this study. Canfield et al. (1984) reported that eosinophil count was higher in adult buffalos than calves. The increase in eosinophils with advancement of age might be adoptive response of the body to various parasitic load or other pathogens exposed to over the period of time. The mean value of monocytes count was within normal physiological range as reported by Jain, 1986. The finding of this study was in conformity with the findings of Abd Ellah et al. (2014) in water buffalo heifers and Ali and Shukla (2012) in normal cyclic post partum buffalos. The finding of this study on basophil level was in agreement with Mayengbam et al. (2018) who reported that basophil level was in the range of $0-1 \%$ in both Sahiwal and Karan Fries cattle breeds at different intervals of thermal exposure. Jacob et al. (2021) reported that basophil count (\%) differed non-significantly between all the ages and physiological stages studied in Gir cattle and Jaffarabadi buffaloes and also between the two species.

\section{Serum biochemical parameters}

Serum glucose value was increased along with the progress of lactation. During early lactation more glucose is needed for lactose synthesis and thus lower glucose level was present in the circulation. The mean serum glucose level in the present study was higher than that reported by Gopalakrishna Rao et al. (1981) and Sharma and Quadri (2001). The finding of this study was in accordance with the findings of Rawat et al. (2006) who reported higher value for indigenous cows. Maintenance of stable glucose concentration depends on hormones like insulin, glucagon, epinephrine, glucocorticoids and thyroid hormones which control regulatory mechanism (Rawat et al., 2006). The mean plasma total protein in our study was lower than that reported by Prakash et al. (2018) in Kankrej and Gir cattle. Prakash et al. (2018) reported that serum albumin levels in cross bred cattle was increased during progression of lactation. The physiological status or lactation stage can change the serum plasma protein level. Serum protein level indicates the balance between anabolism and catabolism of protein in the body and it depends on nutritional status, water consumption and health status (Samanta and Dass, 2007). With advancement of lactation albumin level is decreased, merely because of decresed biosynthesis by the liver in order to cope up from lactation induced metabolic stress (Kulkarni et al., 1983). Serum albumin level of Trinket cattle reported by De et al. (2020) was similar to the finding of this study. The increased BUN values in various breeds have been reported by various authors in various studies. The elevated BUN level is due to enhancement of metabolic activities leading to increased protein catabolism (Dar et al., 2019). The mean creatinine value of Pulikulam cattle found from this study seems to be higher than the creatinine value of Hariana cattle reported by Kumar et al. (2018). In contrast to the present study on serum creatinine, Sreedhar et al. (2013) reported that a non significant difference was observed in serum creatinine levels between Sahiwal heifers and Sahiwal cows. Finding of this study on cholesterol was similar to the value reported by Ramakrishnan et al. (2012) in Gir cows and Mahima et al. (2013) in Hariana cattle. In contrast, Rawat et al. (2006) and Jacob (2012) reported higher cholesterol values in indigenous cattle. The higher value during mid lactation in the present study was due to physiological adjustment to meet lactation requirement (Rawat et al., 2006). Milorad et al. (2013) reported that total cholesterol and triglycerides levels were significantly affected by physiological status.

The average ALT value reported in this study was within the normal physiological range of cattle as 11 to $40 \mathrm{U} / \mathrm{L}$ (Herbert, 1984). The average ALT value of Pulikulam cattle was lower than the Sahiwal cows as reported by Chandra et al. (2012). The mean AST values Pulikulam cattle was lower than the Hariana cattle (Muthukumar et al., 2004), Sahiwal and 
Hardhenu cattle (Kumar et al., 2018). Gomes et al. (2016) reported that mean ALP value of crossbred Holstein with Gir cross bred calves was $303.82 \mathrm{U} / \mathrm{L}$ which was higher than the value noticed in the present study. The mean ALP value of Hariana heifer as reported by Muthukumar et al. (2004) was lower than the Pulikulam animal. The mean total billurubin value of Pulikulam cattle was higher than Hariana cattle and Sahiwal cattle. The mean direct billurubin values of Pulikulam cattle were lower than Hariana and Sahiwal breeds (Kumar et al., 2018).

The finding of this study on serum calcium level was similar to Kumar et al. (2018) who reported the serum calcium level of Hariana cattle was $7.8 \mathrm{mg} / \mathrm{dL}$. Increased serum calcium level during progress of lactation was reported by Rowland et al. (1980) and Nale (2003). The result of this study was similar to findings of Hagawane et al. (2009) who reported the serum phosphorus level in early stage of lactation was lowered than the normal healthy control and other group of buffaloes. The high demand of phosphorus during early stage of production may be the reason for lower level in serum. The average serum magnesium

\section{REFERENCES}

Abd Ellah MR, Hamed MI, Ibrahim DR and Rateb HZ, 2014. Serum biochemical and haematological reference intervals for water buffalo (Bubalus bubalis) heifers. J S Afr Vet Assoc, 85(1): e1-e7, doi: 10.4102/jsava.v85i1.962

Ali R and Shukla SP, 2012. Haemato-biochemical changes in post-partum anoestrus buffaloes during low breeding season. Researcher, 4(9): 55-58

Canfield PJ, Best FG, Fairburn AJ, Purdie J and Gilham M, 1984. Normal haematological and biochemical values for the swamp buffalo (Bubalus bubalis) in Australia. Australian Vet J, 61(3): 89-93, doi: 10.1111/j.1751-0813. 1984.tb15525.x

Chandra B, Singh SV, Hooda OK, Upadhyay RC, Baidya M et al., 2012. Influence of temperature variability on physiological, hematological and biochemical profile of growing and adult Sahiwal level of Hariana cattle reported by Mahima et al. (2013) was lower than Pulikulam cattle. Mamun et al. (2013) reported that there was no significant variation $(\mathrm{p}>0.05)$ in serum magnesium and phosphorus levels observed between male and female native cattle in hilly area of Bangaladesh which was similar to the observation of this study.

The hematological values of Pulikulam cattle were within the normal referral value of bovine species and values of some parameters in serum biochemical were varied than normal referral values of bovine. The hematological and serum biochemical values of Pulikulam cattle breed will be useful for academic purpose and helpful to identify the health and nutritional status of Pulikulam cattle breed.

Conflict of interest: Authors have no conflict of interest in this study.

\section{ACKNOWLEDGEMENT}

The authors are thankful to the Professor and Head, Teaching Veterinary Clinical Complex, Veterinary College and Research Institute, Tirunelveli, Tamil Nadu for the facility provided and sample analysis.

cattle. J Environ Res Develop, 7(2A): 986-994

Cozzi G, Ravarotto L, Gottardo F, Stefani AL, ContieroB et al., 2011. Reference values for blood parameters in Holstein dairy cows: effects of parity, stage of lactation, and season of production. J Dairy Sc, 94(8): 3895-3901, doi: 10.3168/jds.2010-3687

Dar AH, Kumar S, Singh DV, Sodhi M, Sharma RK et al., 2019. Seasonal variation in blood biochemical characteristics of Badri cattle. J Pharma Innov, 8(9): 147-150

De A, Perumal P, George Z, Mondal S, Muniswamy K et al., 2020. Haematology, serum biochemistry and mineral profiles of Trinket cattle, endangered feral cattle associated with the colonial history of Nicobar. Indian J Anim Sci, 90(8): 1109-1114

Deshpande SD, Sawant MK and Vadlamudi VP, 1986. Erythrocytic studies in Red Kandhari cows with 
special reference to pregnancy and lactation. Indian Vet J, 63(10): 807-810

Dhiman TR, Kleinmans J, Tessmann NJ, Radloff, HD, van Evert P et al., 1991. Effect of dietary forage: grain ratio on blood constituents in dairy cows. $\mathrm{J}$ Dairy Sci, 74(8): 2691-2695, doi: 10.3168/ jds.S0022-0302(91)78447-6

Farooq U, Samad HA, Khurshid A and Sajjad S, 2011. Normal reference hematological values of onehumped camels kept in Cholistani desert. J Anim Plant Sci, 21(2): 157-160

Filipejová T and Kováèik J, 2009. Evaluation of selected biochemical parameters in blood plasma, urine and milk of dairy cows during the lactation period. Slovak J Anim Sci, 42(Suppl. 1): 8-12

Gomes LR, Rodrigues RD, de Souza RR, Bizare A, KnychalaFaria JG et al., 2016. Serum biochemistry profile in newborn Senepol and crossbred Holstein x Gir calves aged three to five days in Uberlândia, Minas Gerais, Brazil. Semina: CiênciasAgrárias, 37(3): 1415-1421, doi: 10.5433/1679-0359. 2016v37n3p1415

Gopalakrishna Rao D, Prasad ABA, Krishna VJ and Satyanarayana Rao K, 1981. Studies on some biochemical constituents of blood od Ongole cows. Indian Vet J, 58(11): 870-873

Hagawane SD, Shinde SB and Rajguru DN, 2009. Haematological and blood biochemical profile in lactating buffaloes in and around Parbhani city. Vet World, 2(12): 467-469

Herbert K, 1984. Lipids. In: Clinical Chemistry: Theory, Analysis and Co-relation, (Kalpan, LA and Pesce, AJ Eds), St. Louis, Mosby publishing, Toronto, pp 1182-1230

Ingvartsen KL, 2006. Feeding-and management-related diseases in the transition cow: physiological adaptations around calving and strategies to reduce feeding-related diseases. Anim Feed Sci Technol, 126(3-4): 175-213, doi: 10.1016/ j.anifeedsci.2005.08.003

Jacob N, 2012. Haematological, biochemical and endocrine parameters at different ages and physiological status in Gir cattle and Jafferbadi buffalos. Ph.D thesis submitted to Anand Agricultural University, Gujarat

Jacob N, Arya JS, Padodara RJ and Gajbhiye P, 2019. Haematological assessment of healthy Gir cattle on an established farm. J Entomol Zool Stud, 7(3): 465-469

Jacob N, Padodara RJ, Arya JS and Gajbhiye PU, 2021. WBC differential in Gir and Jaffarabadi animals at different physiological stages. J Entomol Zool stud, 9(2): 1015-1018
Jain NC, 1986. Schalm's Veterinary Hematology, (Edition 4) Lea and Febiger, pp 89-110

Kahn CM, 2010. The Merck Veterinary Manual. $10^{\text {th }}$ edn., Merck \& Co, Inc., Whitehouse Station, NJ, USA. pp 2826

Kapale PM, Jagtap DG, Badukale DM and Sahatpure SK, 2008. Hematological constituents of blood of Gaolao cattle. Vet World, 1(4): 113-114

KhaledNF, Illek J and Gajdùšek S, 1999. Interactions between nutrition, blood metabolic profile and milk composition in dairy goats. Acta Vet Brno, 68(4): 253-258, doi: 10.2754/ avb199968040253

Kulkarni BA, Talvelkar BA, Deshmukh BT, Kolhatkar VP, Patankar DD et al., 1983. Biochemicalstudies in Gir and cross-bred dairy-cows. Indian Vet J, 60(1): 17-22

Kumar D, Kumar S, Gera S and Yadav J, 2018. Comparative assessment of biochemical parameters of Hariana, Hardhenu and Sahiwal breeds. Indian J Anim Res, 52(11): 1565-1568, doi: 10.18805/ijar.B-3405

Lankesh P, Narayanaswamy M, Shrikrishna I, Sudhakar ML and Pradeep N, 2015. Haematological profile in Hallikar cattle at the native tract. Int J Sci EnvironTechnol, 4 (5): 1316-1321

Littlewood RW, 1936. Livestock of Southern India. Published by Government of Madras, pp 95-99

Lumsden JH, Mullen K and Rowe R, 1980. Hematology and biochemistry reference values for female Holstein cattle. Can J Comp Med, 44(1): 24-31

Mahima, Singh KV, Verma AK, Kumar V, Singh, SK et al., 2013. Hematological and serum biochemical profile of apparently healthy Hariana cattle heifers in northern India. Pak J Biol Sci, 16(21): 1423-1425, doi; 10.3923/ pjbs.2013.1423.1425

Mamun MA, Hassan MM, Shaikat AH, Islam SKMA, Hoque MA et al., 2013. Biochemical analysis of blood of native cattle in the hilly area of Bangladesh. Bangladesh J Vet Med, 11(1): 5156, doi: 10.3329/bjvm.v11i1.16513

Mayengbam P, Tolenkhomba TC and Upadhyay RC, 2018. Variation in leukocyte counts of Sahiwal and Karan Fries cattle during acute thermal exposures. In Proceeding of the Mizoram Science Congress (MSC 2018) - Perspective and Trends in the Development of Science Education and Research, doi: 10.2991/msc-18.2018.37

Mazzullo G, Rifici C, Cammarata F, Caccamo G, Rizzo M et al., 2014. Effect of different environmental conditions on some haematological parameters in cow. Ann Anim 
Sci, 14(4): 947-954, doi: 10.2478/aoas-20140049

Milorad K, Djokoviæ R and Bojkovski J, 2013. Determination of charactestic blood organic parameters in periparatal and peak lactation dairy cows. Bulletin UASVM, Vet Med, 70(2): 258-265

Muthukumar G, Das PK, Sanyal S, Roy S and Rajendran D, 2004. Hematological and biochemical profile of Hariana hiefer during estrous and anestrous conditions. Indian J Anim Health, 43(1): 32-36

Nale RA, 2003. Metabolic profiling in cows before and after parturition. M.V.Sc Thesis submitted to MAFSU, Nagpur, pp 29-34

NBAGR weblink https://nbagr.icar.gov.in/en/ registered-cattle/ (21.05.2021)

Osman TEA and Al-Busadah A, 2003. Normal concentrations of twenty serum biochemical parameters of she-camels, cows and ewes in Saudi Arabia. Pak J Biol Sci, 6(14): 1253-1256, doi: 10.3923/pjbs.2003.1253.1256

Prakash MS, Pathan MM, Arya JS and Lunagariya PM, 2018. Assessment of glucose, total protein, albumin and cholesterol level and its correlation with milk production during different stages of lactation in indigenous and crossbred cows. Int J Curr Microbiol App Sci, 7(4): 1248-1256, doi: 10.20546/ijcmas.2018.704.139

Pyne AK and Maitra DN, 1981. Physiological studies on blood of lactating Hariana and Sahiwal cattle. Indian Vet J, 58: 526-528

Raghunandanan KV, Eapen KJ and Bhagi HK, 1977. A comparative study on cellular constituents of blood in Hariana and its crosses with exotic cattle. Indian J Dairy Sci, 30: 348-350

Rama Krishnan A, Dhami AJ, Naikoo M, Patel SB and Savalia FP, 2012. Effect of puerperium, estrus synchronization and post breeding periods on plasma profile of total protein, cholesterol and triglycerides in Gir cows. Indian J Field Vet, 7(4): 17-23

Rawat B, Nigam R and Jain AK, 2006. Metabolic profile in late pregnancy and early lactation in Hariana and crossbred cows. Indian Vet J, 83(7): 795-797

Roland L, Drillich M and Iwersen M, 2014. Hematology as a diagnostic tool in bovine medicine. $\mathrm{J}$ Vet Diagn Invest, 26(5): 592-598, doi: 10.1177/ 1040638714546490

Rowland GJ, Manston R, Stark AJ, Russell AM, Collis KA et al., 1980. Changes in albumin, globulin, glucose and cholesterol concentration in a blood of dairy cows in a late pregnancy and early lactation and relationships with subsequent fertility. J Agric Sci, 94(3): 517-527, doi: $10.1017 /$ S0021859600028501

Ruginosu E, Creangă Ș , Sofronie M, Mălăncuș R, Boghian V et al., 2011. The biochemical profile in cows with reproductive disorders. Cercet Agron Mold, 44(2): 75-86

Sabasthin A, Kumar VG, Nandi S and Murthy VC, 2012. Blood haematological and biochemical parameters in normal cycling, pregnant and repeat breeding buffaloes (Bubalus bubalis) maintained in isothermic and isonutritional conditions. Asian Pacific J Reproduct, 1(2): 117-119, doi: 10.1016/ S2305-0500(13)60061-5

Samanta AK and Dass RS, 2007. Effect of vitamin E supplementation on growth, nutrient utilization, blood biochemical and enzymatic profile in male crossbred (Bos indicus $\times$ Bos taurus) calves. Int J Cow Sci, 3(1-2): 34-43

Seifi HA, Gorji-Dooz M, Mohri M, Dalir-Naghadeh B and Farzaneh N, 2007. Variations of energyrelated biochemical metabolites during transition period in dairy cows. Comp Clin Path, 16(4): 253258, doi: 10.1007/s00580-007-0682-2

Sharma IJ and Quadri MA, 2001. Blood glucose, ketone bodies and gluconeogenic enzyme activities in the lactating cows and buffaloes. CheironMadras Then Chennai, 30(5/6): 172-173

Shil SK, Shaikat AH, Nath BK, Khan MFH and Khan SA, 2012. Hemato-biochemical profile in lactating cows and their calves. J Bangladesh Soc Agric Sci Technol, 9(1\&2): 41-44

Singh PK, Pundir RK, Kumarasamy $\mathrm{P}$ and Vivekanandan, 2012. Management and physical features of migratory Pulikulam cattle of Tamil Nadu. Indian J Anim Sci, 82(12): 1587-1590

Sreedhar S, Rao KS, Suresh J, Moorthy PR and Reddy VP, 2013. changes in haematocrit and some serum biochemical profile of Sahiwal and Jersey $x$ Sahiwal cows in tropical environments. Veterinarski Arhiv, 83(2): 171-187

Srinivasan G and Sathiamoorthy T, 2020. Morphometric characterstics of Pulikulam cattle breed in a nucleus herd. J Entomol Zool Stud, 8 (3):1893-1895

William O Reece, 2004. Dukes Physiology of Domestic Animals. Cornell University Press, pp 31

Received - 02.04.2021, Accepted - 23.05.2021, Published - 01.06.2021

Section Editor: Dr. A. K. Patra, Associate Editor 